Original Article

\title{
The impact of cow dung augmentation on soil restoration and bio-accumulation of metals (Lead and Cadmium) in Pheretima posthuma (Annelida: Clitellata)
}

\author{
O impacto do aumento de esterco de vaca na restauração do solo e bioacumulação de \\ metais (chumbo e cádmio) em Pheretima posthuma (Annelida: Clitellata)
}

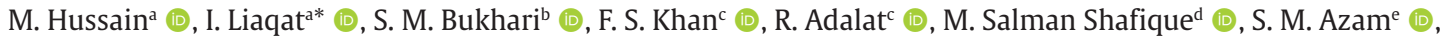

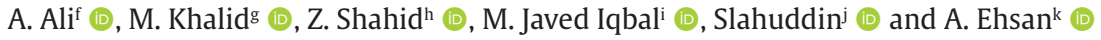 \\ aGC University Lahore, Department of Zoology, Microbiology Lab, Lahore, Pakistan \\ bUniversity of Veterinary and Animal Sciences, Department of Wildlife and Ecology, Lahore, Pakistan \\ 'University of Sialkot, Department of Biotechnology, Sialkot, Pakistan \\ dGC University, Department of Chemistry, Atomic Absorption Lab. and Functional Material Lab., Lahore, Pakistan \\ eUniversity of Education, Division of Science and Technology, Department of Zoology, Lahore, Pakistan \\ 'The Islamia University of Bahawalpur, Department of Zoology, Bahawalpur, Pakistan \\ ${ }^{8}$ Government Emerson College Multan, Department of Zoology, Multan, Pakistan \\ hUniversity of Veterinary and Animal Sciences, Department of Fisheries \& Aquaculture, Lahore, Pakistan \\ 'Bahauddin Zakariya University, Department of Zoology, Multan, Pakistan \\ jUniversityof Gujrat, Department of Zoology, Gujrat, Pakistan \\ ${ }^{\mathrm{k}}$ The University of Lahore, Department of Zoology, Institute of Molecular Biology and Biotechnology, Lahore, Pakistan
}

\begin{abstract}
To investigate the role of cow dung in soil reclamation and bio assimilation along with bio accumulation of heavy metals in earthworm ( $P$. posthuma) $(N=900)$ earthworms were used and treatment groups of $C D$-soil mixture of different proportion of cow dung were designed. Nonlethal doses of lead acetate and cadmium chloride were added in treatment groups. Mature $P$. posthuma were released in each experimental pot maintaining the favorable conditions. The $\mathrm{pH}$, carbon, nitrogen, phosphorus, exchangeable cations, and heavy metal level of each mixture was evaluated. The results indicated that bio-assimilation of $\mathrm{Pb}$ and $\mathrm{Cd}$ by $\mathrm{P}$. posthuma were significantly $(\mathrm{P}<0.01)$ higher in different soil-CD treatments compared to control. Highest bio-assimilation of both metals was observed in $\mathrm{T}^{1}$ of both groups $(\mathrm{Pb}=563.8 \mathrm{mg} / \mathrm{kg}$ and $\mathrm{Cd}=42.95 \mathrm{mg} / \mathrm{kg})$. The contents of both metals were significantly $(\mathrm{P}<0.05)$ lowered in casting. The nutrient concentration in the final castings of all soil-CD treatments were also equally transformed from less or insoluble to more soluble and available for plants, except for carbon level which increased with $C D$ proportion. It is concluded that cow dung as organic matter has a positive effect on soil reclamation and bio-assimilation of metals by $P$. posthuma.
\end{abstract}

Keywords: cow dung, bio-assimilation, heavy metals, soil reclamation, Pheretima posthuma.

\begin{abstract}
RESUMO
Para investigar o papel do esterco de vaca na recuperação do solo e bioassimilação, juntamente com a bioacumulação de metais pesados em minhocas ( $P$. posthuma) $(\mathrm{N}=900)$, minhocas foram usadas e grupos de tratamento de mistura CD-solo de diferentes proporções de esterco de vaca foram projetados. Doses não letais de acetato de chumbo e cloreto de cádmio foram adicionadas aos grupos de tratamento. P. posthuma maduros foram liberados em cada vaso experimental, mantendo as condições favoráveis. Foram avaliados o pH, carbono, nitrogênio, fósforo, cátions trocáveis e nível de metais pesados de cada mistura. Os resultados indicaram que a bioassimilação de $\mathrm{Pb}$ e $C d$ por $P$. posthuma foi significativamente $(P<0,01)$ maior em diferentes tratamentos de solo- $C D$ em relação ao controle. A maior bioassimilação de ambos os metais foi observada em T1 de ambos os grupos ( $\mathrm{Pb}=563,8 \mathrm{mg} / \mathrm{kg}$ e $\mathrm{Cd}=42,95 \mathrm{mg} / \mathrm{kg})$. O conteúdo de ambos os metais foi significativamente $(\mathrm{P}<0,05)$ reduzido na fundição. A concentração de nutrientes nas fundições finais de todos os tratamentos de solo- $C D$ também foi igualmente transformada de menos ou insolúvel para mais solúvel e disponível para as plantas, exceto o nível de carbono que aumenta com a proporção de CD. Conclui-se que o esterco de vaca como matéria orgânica tem um efeito positivo na recuperação do solo e na bioassimilação de metais por P. posthuma.
\end{abstract}

Palavras-chave: esterco de vaca, bioassimilação, metais pesados, recuperação de solo, Pheretima posthuma.

*e-mail: iramlqt@gmail.com; iramliaq@hotmail.com

Received: January 14, 2021 - Accepted: March 3, 2021

This is an Open Access article distributed under the terms of the Creative Commons Attribution License, which permits unrestricted use, distribution, and reproduction in any medium, provided the original work is properly cited. 


\section{Introduction}

Cow dung (CD) is undigested fecal matter of buffaloes and cows. With the increasing demand of cow husbandry, cow dung is also a major challenge to clean the environment. Few decades back, CD was utilized as mosquito repellent, burning fuel and as natural fertilizer in India (Gupta et al., 2016). Besides, CD is being used as food material in earthworm culturing and vermicomposting. Vermicomposting is the process by which epigeic earthworm species are used for conversion of organic wastes into vermicompost (Suthar et al., 2017). CD is used as feed for earthworm because it is easily and readily available during composting process. In the same way, CD was mixed in sewage sludge as source of organic food for vermicomposting (Gupta et al., 2016).

Heavy metals like lead $(\mathrm{Pb})$ and cadmium $(\mathrm{Cd})$ are widely distributed in the terrestrial and aquatic environments from various anthropogenic sources (Selvi et al., 2019). These metals are assimilated in body tissue of earthworms by ingesting contaminated soil (Pattnaik and Reddy, 2011). After absorption, heavy metals combine with enzymes and inhibit the proper function of enzymes (Duruibe et al., 2007). This may cause severe physiological and neurological consequences in human (Žaltauskaitè and Sodienè, 2010). $\mathrm{Pb}$ pollution is $10 \%$ of total pollution caused by heavy metals because it is abundantly utilized in lead-acid batteries, gasoline alkyl addition, building construction, paints, cable coating, petrol refining and others (Tchounwou et al., 2012). Pb also exerts negative effects on both growth and leaf expansion of plants (84). High concentration of $\mathrm{Pb}$ can damage liver, lungs, kidney, digestive tract and nervous system of humans by changing the normal metabolic processes (Jaishankar et al., 2014).

Like $\mathrm{Pb}, \mathrm{Cd}$ is extremely important with respect to its toxicity, high mobility and water solubility (Duruibe et al.,
2007). The major sources of $\mathrm{Cd}$ are fertilizers, Ni-Cd batteries, paint, PVC plastics, fungicides, insecticides, and sludge. $\mathrm{Cd}$ concentration is very high in the crops and grains grown in the polluted areas and irrigated with polluted water (Hussain et al., 2019). After absorption, metals like Cd are mainly accumulated in the liver, gall bladder, muscles, thyroid, lungs, kidney, pancreas, and other tissues (Tchounwou et al., 2012).

Earthworms act in the soil as aerators, grinders, crushers, chemical degraders, and the biological stimulators (Sharma et al., 2017a). These worms play significant role in soil restoration process to increase fertility and remove soil contaminants (Butt, 2008). Pheretima posthuma (Kinberg, 1867) belongs to the group of epigeic earthworms that extensively found along various crop fields in Pakistan (Sial et al., 2017). Concentration of metal accumulation in earthworm body tissues is concerned with the bioavailable level of heavy metal within soil (Liu et al., 2012). Different environmental factors are correlated with bioaccumulation of heavy metals such as temperature, $\mathrm{pH}$, humidity, and organic matter contents (Sial et al., 2017). With all this background, this current study has been designed to investigate the role of cowdung in soil reclamation with earthworm (P. posthuma) by bio-assimilation and its effect on bioaccumulation of heavy metals ( $\mathrm{Pb}$ and $\mathrm{Cd}$ ).

\section{Materials and Methods}

\subsection{Sample organism, soil and cowdung}

Earthworms (as sample organism) were collected at the depth of 30-50 cm, during August-October of 2019, from the Maralah Ravi Link (32²2'25.4"N 74²4'54.9”E) near Motra Canal Bridge Daska Pakistan, using digging method (Figure 1). Soil samples were also obtained from same site

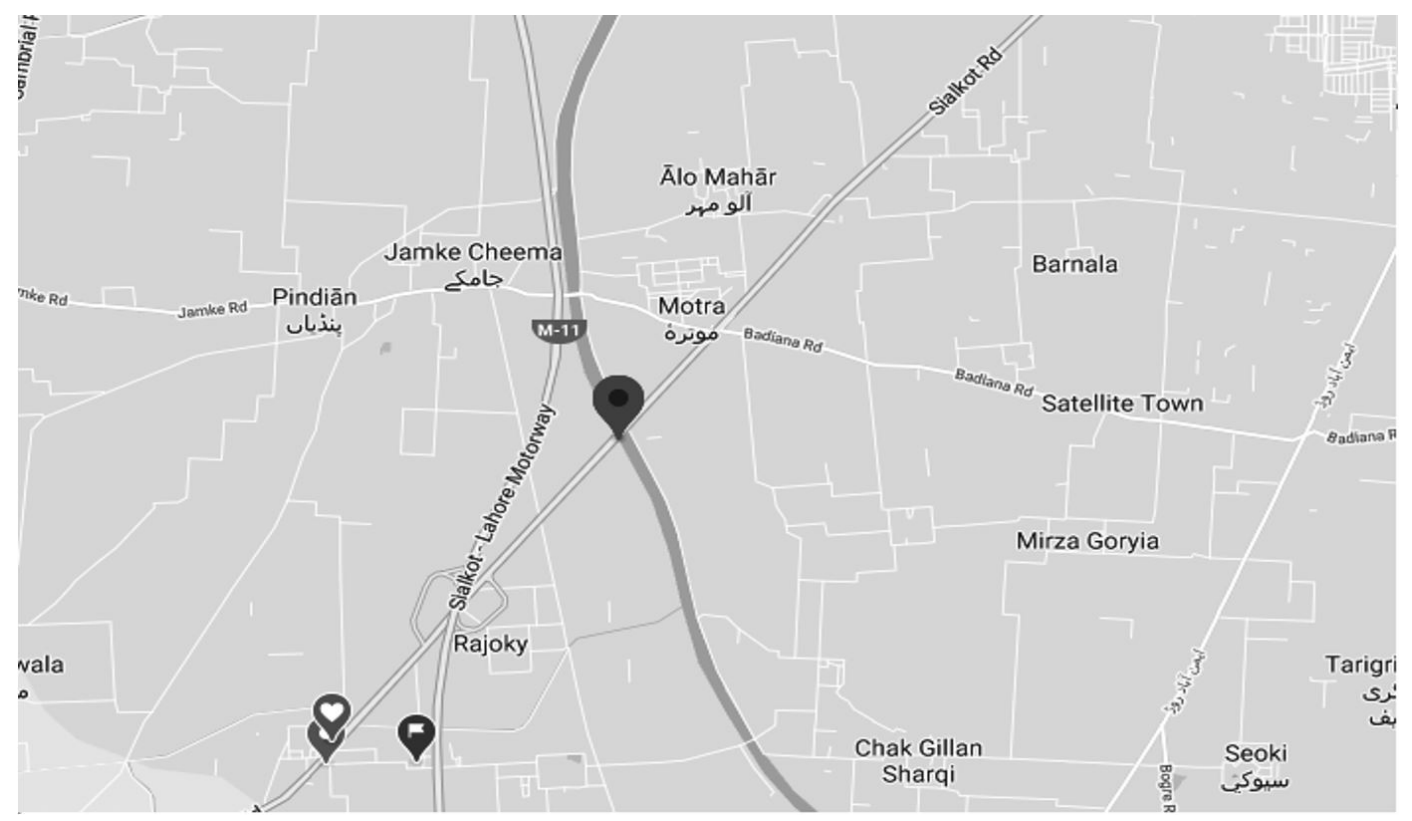

Figure 1. Sampling site near Daska Sialkot. 
at same depth, and time. To form soil-CD mixture, cow dung samples were collected from dairy farms in Daska city, Pakistan.

\subsection{Experimental design}

The experiment was performed in two groups each group divided into further four treatments i.e. $\mathrm{T}^{1}, \mathrm{~T}^{2}, \mathrm{~T}^{3}, \mathrm{~T}^{4}$ and control group $\left(\mathrm{T}^{\mathrm{c}}\right.$ ) without any $\mathrm{CD}$ dosage (Suthar and Singh 2009). Fifteen plastic spherical pots $(10 \mathrm{~cm} \times 10 \mathrm{~cm})$ were utilized for each group and each pot consist of $250 \mathrm{~g}$ soil-CD mixture with different $\mathrm{CD}(\%)$ proportions such as $\mathrm{T}^{1}(2 \%), \mathrm{T}^{2}(4 \%), \mathrm{T}^{3}(6 \%), \mathrm{T}^{4}(8 \%)$ and $\mathrm{T}^{\mathrm{c}}(0 \%)$ (Kumar et al., 2008). Soil-CD mixture and metals were taken in plastic pots as shown in Table 1. Double distilled water was added, yielding moisture of $\sim 50-70 \%$ and was kept constant throughout the experiment by spraying (Suthar and Singh, 2009). Prior to adding earthworm, all the experimental pots with soil-CD mixture were placed in shady area for four weeks. Mature $P$. posthuma worms ( $n=10, \approx$ weight $220 \mathrm{~g}$ ) were released in pots with porous lid and kept in dark ( $27-37^{\circ} \mathrm{C}, 50-70 \%$ moisture content and $\left.\mathrm{pH} \sim 6.0-7.5\right)$ throughout the experiment composting period (Eltejani and Abdel, 2017).

After 28 days metal exposure, the earthworms gut content (Pattnaik and Reddy, 2011) and castings were collected (Hidalgo and Harkess, 2002). Gut cleared earthworms were then placed in beakers and dried in a TK/L 4105 (EHRET) at $60{ }^{\circ} \mathrm{C}$ for 48 hours and weighed. Dry earthworms were then digested following the method by Wang et al. (2018). Samples were then diluted, centrifuged and subjected to flame atomic absorption spectrophotometer (FAAS) analysis in High Tech Laboratory, University of agriculture Faisalabad following the method of (Zhang and Reynolds, 2019). Like earthworm tissues, 1 $\mathrm{g}$ each of soil, cow dung, soil-CD mixture and castings of different treatments were also analyzed to check metal concentrations through FAAS.

Nutrient content analysis of homogenized substrate and cow dung soil sample was done following the method of Al-Busaidi et al. (2005), Yoon et al. (2018), Horta and Torrent (2007) and Le Roux et al. (2016). Bio-assimilation factors BAF was calculated following Mountouris et al. (2002).

\subsection{Statistical analysis}

One-way analysis of variance (ANOVA) was used to analyze the significant difference between cow dung treatments of initial substrates, earthworm tissues and earthworm casting. Duncan's Multiple Range Test (DMR) was applied to compare the means of different cow dung treatments.

\section{Results}

At the beginning, metal concentrations in initial substrate were analyzed before adding the $\mathrm{Pb}$ and $\mathrm{Cd}$ concentration. The concentrations of $\mathrm{Pb}$ and $\mathrm{Cd}$ in soil are shown in Table 2. These non-lethal metal levels were non-significant and statistically similar for $\mathrm{Pb}(\mathrm{F}=0.0681$, $\mathrm{P}>0.05)$ and $\mathrm{Cd}(\mathrm{F}=0.2901, \mathrm{P}>0.05)$ in all initial substrates for different cow dung treatments. Following incubation period of four weeks, in tissues of $P$. posthuma, the concentration of $\mathrm{Pb}$ against different $\mathrm{Pb}$ polluted soil- $\mathrm{CD}$ treatments were found highly significant $(F=9.201, P<0.01)$ as shown in column 4 of Table 2 . The concentration of $\mathrm{Pb}$, after vermicompost, declined in all treatments. According to DMR analysis, $\mathrm{T}^{\mathrm{c}}, \mathrm{T}^{1}$ and $\mathrm{T}^{2}$ showed significantly lower metal level as compared to $\mathrm{T}^{3}$ and $\mathrm{T}^{4}$.

The content of $\mathrm{Pb}$ in earthworm casting was decreased compared to initial soil-CD mixture which assured that it must be assimilated in earthworm tissues as shown in Table 2.

The ranges of BAFs for $\mathrm{Pb}$ and $\mathrm{Cd}$ metals were recorded between $0.5235-0.6246$ and 0.4864-0.6642 respectively. These higher values of BAFs described the bioavailability of $\mathrm{Pb}$ and $\mathrm{Cd}$ in all treatments for $P$. posthuma. But it was observed highest in $\mathrm{T}^{1}$ treatments for both $\mathrm{Pb}$ and $\mathrm{Cd}$, 0.6246 and 0.6642 respectively as shown in Figure 2 .

The results regarding to nutrient contents in different soil-cow dung treatments are summarized in Table 3.

\section{Discussion}

In the present study, analysis of $\mathrm{Pb}$ and $\mathrm{Cd}$ concentrations in initial substrate indicated the presence of these metals in soil and $\mathrm{CD}$ samples. Additional doses of $\mathrm{Pb}$ and $\mathrm{Cd}$ concentrations in all treatments were found non-lethal as observed by no death throughout the experimental period. These tolerable values for earthworms were comparable to $\mathrm{Pb}<2500$ and $\mathrm{Cd}<100 \mathrm{mg} / \mathrm{kg}$ (Kumar et al., 2008; Zhang and Reynolds, 2019). In regarding to heavy metal toxicity, literature proved the earthworms have a capability to tolerate bioavailable metals because of physiological familiarization and genetic variability (Nirola et al., 2016).

Table 1. Soil-CD mixture proportions contaminated with $\mathrm{Pb}$ and $\mathrm{Cd}$.

\begin{tabular}{ccccccc}
\hline Treatments & \%age of S+CD & Soil (g) & CD (g) & $\begin{array}{c}\text { Soil-CD } \\
\text { Mixture (g) }\end{array}$ & $\begin{array}{c}\text { Group I Pb } \\
\text { (mg) }\end{array}$ & $\begin{array}{c}\text { Group II Cd } \\
\text { (mg) }\end{array}$ \\
\hline $\mathbf{T}^{\mathbf{c}}$ & $\mathrm{S}(100 \%)+\mathrm{CD}(0 \%)$ & 250 & 0 & 250 & 450 & 20 \\
$\mathbf{T}^{\mathbf{1}}$ & $\mathrm{S}(98 \%)+\mathrm{CD}(2 \%)$ & 245 & 5 & 250 & 450 & 20 \\
$\mathbf{T}^{2}$ & $\mathrm{~S}(96 \%)+\mathrm{CD}(4 \%)$ & 240 & 10 & 250 & 450 & 20 \\
$\mathbf{T}^{3}$ & $\mathrm{~S}(94 \%)+\mathrm{CD}(6 \%)$ & 235 & 15 & 250 & 450 & 20 \\
$\mathbf{T}^{4}$ & $\mathrm{~S}(92 \%)+\mathrm{CD}(8 \%)$ & 230 & 20 & 250 & 450 & 20 \\
\hline
\end{tabular}

Note: $\mathrm{T}^{\mathrm{c}}$ (Control treatment); $\mathrm{T}^{1}$ (Treatment 1); $\mathrm{T}^{2}$ (Treatment 2); $\mathrm{T}^{3}$ (Treatment 3); $\mathrm{T}^{4}$ (Treatment 4); $\mathrm{S}$ (soil); CD (Cow dung); Pb (Lead); and Cd (Cadmium). 
Table 2. Comparison of $\mathrm{Pb}$ and $\mathrm{CD}$ concentrations in initial substrate, $P$. posthuma casting and tissue.

\begin{tabular}{ccccccc}
\hline Treatments $^{\mathbf{r}}$ & Pb in I.S & Pb in E.C & Pb in E.T & CD in I.S & CD in E.C & CD in E.T \\
\hline $\mathbf{T}^{\mathrm{c}}$ & $904.55 \pm 3.41^{\mathrm{a}}$ & $378.5 \pm 9.98^{\mathrm{a}}$ & $481.0 \pm 19.81^{\mathrm{b}}$ & $63.44 \pm 2.2^{\mathrm{a}}$ & $25.21 \pm 1.5^{\mathrm{b}}$ & $30.86 \pm 1.16^{\mathrm{b}}$ \\
$\mathbf{T}^{1}$ & $902.06 \pm 4.38^{\mathrm{a}}$ & $331.4 \pm 10.34^{\mathrm{b}}$ & $563.4 \pm 11.21^{\mathrm{a}}$ & $64.66 \pm 1.02^{\mathrm{a}}$ & $27.38 \pm 1.11^{\mathrm{b}}$ & $42.95 \pm 1.72^{\mathrm{a}}$ \\
$\mathbf{T}^{2}$ & $903.64 \pm 2.85^{\mathrm{a}}$ & $369.5 \pm 12.72^{\mathrm{a}}$ & $501.8 \pm 13.92^{\mathrm{b}}$ & $64.25 \pm 0.37^{\mathrm{a}}$ & $26.97 \pm 2.2^{\mathrm{b}}$ & $34.19 \pm 1.85^{\mathrm{b}}$ \\
$\mathbf{T}^{3}$ & $903.20 \pm 3.01^{\mathrm{a}}$ & $388.6 \pm 19.81^{\mathrm{a}}$ & $484.8 \pm 19.78^{\mathrm{b}}$ & $63.96 \pm 1.76^{\mathrm{a}}$ & $31.43 \pm 1.4^{\mathrm{a}}$ & $33.63 \pm 1.41^{\mathrm{b}}$ \\
$\mathbf{T}^{4}$ & $902.72 \pm 2.99^{\mathrm{a}}$ & $392.4 \pm 12.11^{\mathrm{a}}$ & $472.6 \pm 18.78^{\mathrm{b}}$ & $64.74 \pm 1.01^{\mathrm{a}}$ & $30.15 \pm 1.19^{\mathrm{a}}$ & $32.14 \pm 1.57^{\mathrm{b}}$ \\
ANOVA & & & & & \\
F value & 0.068 & 5.052 & 9.201 & 0.29 & 9.213 & 4.228 \\
P value & 0.99 & 0.011 & 0.002 & 0.877 & 0.002 & 0.029 \\
Significance & N.S & $* *$ & $* *$ & N.S & $* *$ \\
\hline
\end{tabular}

rRefer to the Table 1 for description. All values represent mean $(\mathrm{mg} / \mathrm{kg}) \pm$ SD of triplicates. I.S (Initial substrate); E.C (Earthworm casting); and E.T (Earthworm tissue). Superscript a and b letters indicate comparison of mean values by Duncan's Multiple Range Test. If $P>0.05=$ Non-significant (N.S), $\mathrm{P}<0.05=$ Significant $\left({ }^{*}\right)$ and $\mathrm{P}<0.01=$ highly significant $\left({ }^{* *}\right)$. Superscripts $\mathrm{c}, 1,2,3$, and 4 showed the control and number of treatments respectively.

Table 3. Nutrients analysis in initial substrate and final castings after earthworm processing.

\begin{tabular}{|c|c|c|c|c|c|c|c|c|}
\hline \multirow{2}{*}{ Treatments $^{\mathrm{r}}$} & \multicolumn{2}{|c|}{ pH } & \multicolumn{2}{|c|}{$C_{\text {organic }}(g / \mathbf{k g})$} & \multicolumn{2}{|c|}{$\mathrm{N}_{\text {total }}(\mathrm{g} / \mathrm{kg})$} & \multicolumn{2}{|c|}{$\mathrm{C} / \mathrm{N}$ ratio } \\
\hline & IS & FC & IS & FC & IS & FC & IS & FC \\
\hline $\mathbf{T}^{\mathrm{c}}$ & $7.55 \pm 0.09$ & $6.9 \pm 0.12$ & $285.43 \pm 0.52$ & $235.43 \pm 0.72$ & $16.43 \pm 0.40$ & $25.87 \pm 0.23$ & $14.32 \pm 0.20$ & $9.10 \pm 0.34$ \\
\hline $\mathbf{T}^{1}$ & $7.70 \pm 0.11$ & $7.3 \pm 0.17$ & $295.85 \pm 0.23$ & $245.85 \pm 0.61$ & $18.98 \pm 0.36$ & $30.98 \pm 0.30$ & $12.95 \pm 0.34$ & $7.93 \pm 0.46$ \\
\hline $\mathbf{T}^{2}$ & $7.16 \pm 0.13$ & $7.5 \pm 0.50$ & $310.86 \pm 0.45$ & $259.18 \pm 0.49$ & $21.34 \pm 0.56$ & $37.67 \pm 0.49$ & $12.14 \pm 0.41$ & $6.88 \pm 0.50$ \\
\hline $\mathbf{T}^{3}$ & $7.55 \pm 0.19$ & $7.6 \pm 0.15$ & $321.72 \pm 0.32$ & $268.57 \pm 0.71$ & $25.78 \pm 0.69$ & $40.31 \pm 0.56$ & $10.41 \pm 0.59$ & $6.66 \pm 0.41$ \\
\hline \multirow[t]{3}{*}{$\mathbf{T}^{4}$} & $7.32 \pm 0.08$ & $7.2 \pm 0.13$ & $330.21 \pm 0.61$ & $278.71 \pm 0.32$ & $28.61 \pm 0.82$ & $\begin{array}{l}32.65 \pm \\
0.182\end{array}$ & $9.74 \pm 0.53$ & $8.53 \pm 0.25$ \\
\hline & \multicolumn{2}{|c|}{$P_{\text {Bio-a }}(g / \mathbf{k g})$} & \multicolumn{2}{|c|}{$\mathrm{K}^{+}{ }_{\text {Exch }}(\mathrm{g} / \mathbf{k g})$} & \multicolumn{2}{|c|}{$\mathrm{Ca}^{2+}{ }_{\text {Exch }}(\mathrm{g} / \mathbf{k g})$} & \multicolumn{2}{|c|}{$\mathrm{Mg}^{2+}{ }_{\text {Exch }}(\mathrm{g} / \mathbf{k g})$} \\
\hline & IS & FC & IS & FC & IS & FC & IS & FC \\
\hline $\mathbf{T}^{\mathrm{c}}$ & $8.45 \pm 0.15$ & $10.7 \pm 0.12$ & $3.25 \pm 0.11$ & $7.28 \pm 0.08$ & $18.85 \pm 0.15$ & $20.23 \pm 0.18$ & $23.1 \pm 0.34$ & $30.73 \pm 0.29$ \\
\hline $\mathbf{T}^{1}$ & $10.20 \pm 0.20$ & $15.65 \pm 0.15$ & $5.85 \pm 0.15$ & $9.25 \pm 0.21$ & $26.45 \pm 0.25$ & $29.15 \pm 0.13$ & $21.45 \pm 0.25$ & $34.32 \pm 0.33$ \\
\hline $\mathbf{T}^{2}$ & $15.95 \pm 0.12$ & $20.5 \pm 0.16$ & $7.71 \pm 0.17$ & $12.05 \pm 0.27$ & $29.34 \pm 0.37$ & $32.35 \pm 0.37$ & $27.31 \pm 0.27$ & $30.19 \pm 0.48$ \\
\hline $\mathbf{T}^{3}$ & $24.80 \pm 0.09$ & $28.65 \pm 0.19$ & $9.65 \pm 0.21$ & $19.45 \pm 0.22$ & $35.25 \pm 0.11$ & $40.41 \pm 0.29$ & $25.45 \pm 0.41$ & $33.51 \pm 0.49$ \\
\hline $\mathbf{T}^{4}$ & $29.25 \pm 0.14$ & $35.85 \pm 0.18$ & $10.45 \pm 0.19$ & $17.35 \pm 0.46$ & $40.23 \pm 0.23$ & $46.15 \pm 0.36$ & $28.31 \pm 0.63$ & $32.53 \pm 0.62$ \\
\hline
\end{tabular}

Refer to the Table 1 for description. All values showed mean \pm SD of $3 n$, Where IS (initial substrate) and FC (Final casting).

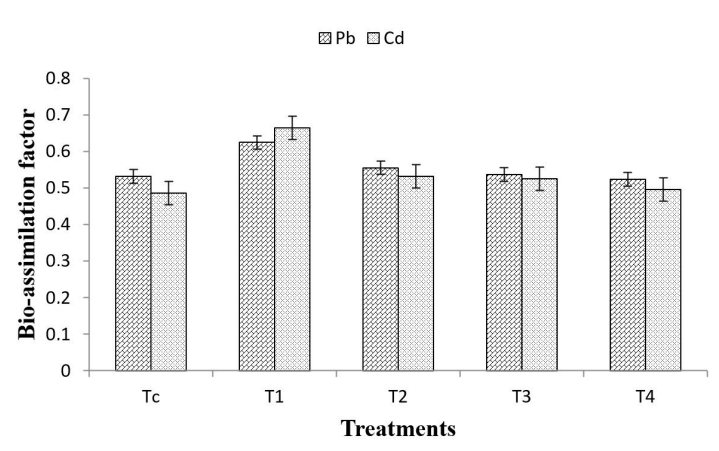

Figure 2. Bio-assimilation factor of $\mathrm{Pb}$ and $\mathrm{Cd}$ in all treatments.
The findings of this study clearly revealed that cow dung showed significant effect on bio-assimilation of $\mathrm{Pb}$ and $\mathrm{Cd}$ in the P. posthuma tissues during composting or remediation process. Previous studies reported that the effect of organic material enhanced the uptake of the metal concentration due to amendment of poultry, pig and cow manure as organic waste (Li et al., 2010). Likewise, heavy metal bioaccumulations in the tissues of Pheretima genera of earthworm were also reported (Muhammad et al., 2010). The use of cow dung as an additional dose to observe its effect on bioaccumulations/ bioassimilations of available heavy metals ( $\mathrm{Zn}, \mathrm{Pb}$ and $\mathrm{Cd}$ ) in earthworm tissues (L. violaceus) was generally low and time dependent (Dada et al., 2016). These variations in 
results might be due to different species (Nannoni et al., 2014), metal bioavailable concentrations in substrates (Liu et al., 2017) and metal physiological tolerance or ecological habitat (Demuynck et al., 2014). The positive effect of cow dung on bio-assimilation of heavy metals $(\mathrm{Pb}-\mathrm{Cd})$ from environment and aqueous solution was due to its absorbent property with metals ions (Ojedokun and Bello, 2016; Vijver et al., 2003).

It was also observed that $P$. posthuma had more $\mathrm{Pb}$ than $\mathrm{Cd}$ showing higher availability of $\mathrm{Pb}$ in soil- $\mathrm{CD}$ mixture compared to Cd. But, Cd accumulation in earthworm (Eudrilus eugeniae) tissues was more than that of $\mathrm{Pb}$ which was opposite to present study (Pattnaik and Reddy, 2011). This change in bio-assimilation and uptake of heavy metals by earthworm tissues could be due to exposure rout or particle size of amendments, dietary habits (Vijver et al., 2005) and behavioral adaptations (Pattnaik and Reddy, 2011; Wang et al., 2018). Furthermore, ingestion of any organic matter containing metals is big source of metal uptake by earthworms (Nannoni et al., 2014). Meanwhile, small sized cysteine rich proteins (i.e. metallothioneins) found in tissues bind metal elements, which were regulated and eliminated by earthworms (He et al., 2016).

$\mathrm{Pb}$ and $\mathrm{Cd}$ concentrations in earthworm casting or vermicompost were reduced due to bio-assimilation of these metal elements in $P$. posthuma tissues. In a same way, some researcher reported the reduced level of heavy metals ( $\mathrm{Pb}$ and $\mathrm{Cd}$ ) in worm casting in relation to the parent mixtures (Kujawska and Wójcik-Oliveira, 2019). As the organic waste mixed in soil passing through elementary tract of earthworms, where the soluble form of heavy metals assimilated and increased in worm's tissues which ultimately decrease the metal concentration in worm's casting (Pattnaik and Reddy, 2011). These results also collaborate with the findings of previous works which indicated the capabilities of earthworms in eliminating bioavailable metals in industrial waste (Azizi et al., 2013).

The values of bio-assimilation factor (BAF) in all soil-CD treatments suggested that both $\mathrm{Pb}$ and $\mathrm{Cd}$ were greatly assimilated in body tissues of earthworm $P$. posthuma while it was highest in $\mathrm{T}^{1}$ treatments. These values of BAFs also indicated that the bioavailability of $\mathrm{Pb}$ and $\mathrm{Cd}$ were higher in P. posthuma tissues and lowered in soil-CD (Suthar and Singh, 2009). This reduction in bioavailable metals in soil-CD was due to assimilation in P. posthuma during composting process through two physiological adaptations in earthworm's cellular tissues: first, binding of these metals with nuclear proteins; second, increase in production level of special binding proteins, metallothionein, within earthworm chloragogenous tissues (Singh and Kalamdhad, 2016).

As the concentrations of $C D$ increased, in soil-CD treatments, the BAFs values were decreased in all treatments (except $\mathrm{T}^{1}$ ) due to formation of organometallic complexes (CD as organic source) which reduce the uptake of heavy metals (Singh and Kalamdhad, 2013). However, the BAFs values examined in this work were decreased compared to previous workers (Wang et al., 2018). This BAFs values difference might be due to varies concentrations of the metals (Hobbelen et al., 2006), exposure period (Pattnaik and Reddy, 2011), habitat variations, food preferences (Quenea et al., 2009), metabolic physiology and earthworm species specificity (Wu et al., 2020). The high levels of BAFs for $\mathrm{Pb}$ and $\mathrm{Cd}$ metals were not only helpful in soil reclamation but could also be a big threat due to the entrance of toxic metals in the food chain via earthworms, if inoculated earthworms are not properly managed.

The nutrient level of processed soil contents indicate that earthworm have potential role in soil reclamation and soil structure (Sharma et al., 2017b). Similarly, Literature revealed that earthworm played a significant role in recycling and transformation of nutrients by changing soil biological, chemical and physical properties. In this work, the nutrient available carbon contents, CD as additional organic carbon source, in final substrate was reduced by vermicomposting activity. The findings were parallel with results of the worm composting in sewage sludge (Suthar and Singh, 2009) and green weeds substrate (Singh and Kalamdhad, 2013). This is because, most of the carbohydrates (i.e polysaccharides) were metabolically assimilated in the P. posthuma body from substrates and some were loss as $\mathrm{CO}_{2}$ in atmosphere due to microbial respiration by decomposers (Liu et al., 2012). The data of current study indicated that the metabolic activities in earthworm body enhance the formation mineral nitrogen in soil. As the earthworm intake soil, containing plant's particles, microbial flora and organic-mineral aggregates, the digestion and metabolism of these contents increase the potential level of mineral nitrogen in composted substrate (Araujo et al., 2004). Similarly, the composted soil-CD also showed a reliable increase in level of available plant's nutrients such as phosphorus and exchangeable ions $\left(\mathrm{K}^{1+}, \mathrm{Ca}^{2+} \& \mathrm{Mg}^{2+}\right)$. It was found that the level of total minerals in all treatments was increased during after vermicomposting. These findings agreed with the results of many pervious works (Hait and Tare, 2011). As the nutrients like inorganic nitrogen, phosphorous and exchangeable cations are required in very small amount for metabolic activities and bogy maintenance in earthworm, so most of the mineral contents released through undigested matter (Aira et al., 2007). The engulfing process of earthworms, occurrence of numerous types of microbial communities and enzymes during substrate composting transformed the insoluble large plants contents into more available and soluble forms, thereby enhancing their level in the composted substrate (Singh and Kalamdhad, 2013).

\section{Conclusion}

The study of $C D$ effect on soil reclamation and bio-assimilation of heavy metals (i.e. $\mathrm{Pb}$ and $\mathrm{Cd}$ ) showed that it has positive effect in all treatments, as organic material bind dissolve metal ions and enter in earthworm body through digestive route. The addition of cow dung in soil enhance the assimilation of heavy metals ( $\mathrm{Pb}$ and $\mathrm{Cd}$ ) in all treatments and highest in $\mathrm{CD}^{\mathrm{a}}$. For soil reclamation, it was concluded that carbon contents were reduced in composted soil due to absorption and consumption in earthworm body while all other available and exchangeable 
mineral cations were increased in castings, as these are required in small quantity.

\section{Acknowledgements}

We are cordially thankful to the director of High Tech Laboratory, University of agriculture Faisalabad for proper guidance and utilization of Hitachi Polarized Zeeman Atomic Absorption Spectrometer (Model: Z8200) to analyze heavy metal concentration.

\section{References}

AIRA, M., MONROY, F. and DOMÍNGUEZ, J., 2007. Earthworms strongly modify microbial biomass and activity triggering enzymatic activities during vermicomposting independently of the application rates of pig slurry. The Science of the Total Environment, vol. 385, no. 1-3, pp. 252-261. http://dx.doi. org/10.1016/j.scitotenv.2007.06.031. PMid:17628641.

AL-BUSAIDI, A., COOKSON, P. and YAMAMOTO, T., 2005. Methods of $\mathrm{pH}$ determination in calcareous soils: use of electrolytes and suspension effect. Soil Research, vol. 43, no. 4, pp. 541-545. http://dx.doi.org/10.1071/SR04102.

ARAUJO, Y., LUIZÃO, F.J. and BARROS, E., 2004. Effect of earthworm addition on soil nitrogen availability, microbial biomass and litter decomposition in mesocosms. Biology and Fertility of Soils, vol. 39, no. 3, pp. 146-152. http://dx.doi.org/10.1007/ s00374-003-0696-0.

AZIZI, A.B., LIM, M.P.M., NOOR, Z.M. and ABDULLAH, N., 2013. Vermiremoval of heavy metal in sewage sludge by utilising Lumbricus rubellus. Ecotoxicology and Environmental Safety, vol. 90, pp. 13-20. http://dx.doi.org/10.1016/j.ecoenv.2012.12.006. PMid:23294636.

BUTT, K.R., 2008. Earthworms in soil restoration: lessons learned from United Kingdom case studies of land reclamation. Restoration Ecology, vol. 16, no. 4, pp. 637-641. http://dx.doi. org/10.1111/j.1526-100X.2008.00483.x.

DADA, E.O., NJOKU, K.L., OSUNTOKI, A.A. and AKINOLA, M.O., 2016. Heavy metal remediation potential of a tropical wetland earthworm, Libyodrilus violaceus (Beddard). Iranian (Iranica). Journal of Energy and Environment, vol. 7, no. 3, pp. 247-254.

DEMUYNCK, S., SUCCIU, I.R., GRUMIAUX, F., DOUAY, F. and LEPRÊTRE, A., 2014. Effects of field metal-contaminated soils submitted to phytostabilisation and fly ash-aided phytostabilisation on the avoidance behaviour of the earthworm Eisenia fetida. Ecotoxicology and Environmental Safety, vol. 107, pp. 170-177. http://dx.doi.org/10.1016/j.ecoenv.2014.05.011. PMid:24949898.

HORTA, M.C. and TORRENT, J., 2007. The Olsen P method as an agronomic and environmental test for predicting phosphate release from acid soils. Nutrient Cycling in Agroecosystems, vol. 77, no. 3, pp. 283-292. http://dx.doi.org/10.1007/s10705006-9066-2.

DURUIBE, J.O., OGWUEGBU, M.O.C. and EGWURUGWU, J.N., 2007. Heavy metal pollution and human biotoxic effects. International Journal of Physical Sciences, vol. 2, no. 5, pp. 112-118.

ELTEJANI, M. and ABDEL, O., 2017. Temperature compensation in pH meter-a survey. Journal of Engineering and Computer Science, vol. 16, no. 2, pp. 1-9.

GUPTA, K.K., ANEJA, K.R. and RANA, D., 2016. Current status of cow dung as a bioresource for sustainable development. Bioresources and Bioprocessing, vol. 3, no. 1, pp. 28. http://dx.doi.org/10.1186/ s40643-016-0105-9.

HAIT, S. and TARE, V., 2011. Vermistabilization of primary sewage sludge. Bioresource Technology, vol. 102, no. 3, pp. 2812-2820. http://dx.doi.org/10.1016/j.biortech.2010.10.031. PMid:21036608.

HE, X., ZHANG, Y., SHEN, M., ZENG, G., ZHOU, M. and LI, M., 2016. Effect of vermicomposting on concentration and speciation of heavy metals in sewage sludge with additive materials. Bioresource Technology, vol. 218, pp. 867-873. http://dx.doi. org/10.1016/j.biortech.2016.07.045. PMid:27434304.

HIDALGO, P.R. and HARKESS, R.L., 2002. Earthworm castings as a substrate amendment for chrysanthemum production. HortScience, vol. 37, no. 7, pp. 1035-1039. http://dx.doi. org/10.21273/HORTSCI.37.7.1035.

HOBBELEN, P.H.F., KOOLHAAS, J.E. and VAN GESTEL, C.A.M., 2006. Bioaccumulation of heavy metals in the earthworms Lumbricus rubellus and Aporrectodea caliginosa in relation to total and available metal concentrations in field soils. Environmental Pollution, vol. 144, no. 2, pp. 639-646. http://dx.doi.org/10.1016/j. envpol.2006.01.019. PMid:16530310.

HUSSAIN, S., HABIB-UR-REHMAN, M., KHANAM, T., SHEER, A., KEBIN, Z. and JIANJUN, Y., 2019. Health risk assessment of different heavy metals dissolved in drinking water. International Journal of Environmental Research and Public Health, vol. 16, no., 10, pp. 1737. http://dx.doi.org/10.3390/ijerph16101737. PMid:31100926.

JAISHANKAR, M., TSETEN, T., ANBALAGAN, N., MATHEW, B.B. and BEEREGOWDA, K.N., 2014. Toxicity, mechanism and health effects of some heavy metals. Interdisciplinary Toxicology, vol. 7, no. 2, pp. 60-72. http://dx.doi.org/10.2478/intox-2014-0009. PMid:26109881.

KUJAWSKA, J. and WÓJCIK-OLIVEIRA, K., 2019. Effect of vermicomposting on the concentration of heavy metals in soil with drill cuttings. Journal of Ecological Engineering, vol. 20, no. 1, pp. 152. http://dx.doi.org/10.12911/22998993/93868.

KUMAR, S., SHARMA, V., BHOYAR, R.V., BHATTACHARYYA, J.K. and CHAKRABARTI, T., 2008. Effect of heavy metals on earthworm activities during vermicomposting of municipal solid waste. Water Environment Research, vol. 80, no. 2, pp. 154-161. http://dx.doi.org/10.1002/j.1554-7531.2008.tb00339.x. PMid: 18330226.

LE ROUX, S., BAKER, P. and CROUCH, A., 2016. Bioaccumulation of total mercury in the earthworm Eisenia andrei. SpringerPlus, vol. 5, no. 1, pp. 681. http://dx.doi.org/10.1186/s40064-0162282-6. PMid:27347466.

LI, L., XU, Z., WU, J. and TIAN, G., 2010. Bioaccumulation of heavy metals in the earthworm Eisenia fetida in relation to bioavailable metal concentrations in pig manure. Bioresource Technology, vol. 101, no. 10, pp. 3430-3436. http://dx.doi.org/10.1016/j. biortech.2009.12.085. PMid:20080399.

LIU, J., LU, Z., YANG, J., XING, M., YU, F. and GUO, M., 2012. Effect of earthworms on the performance and microbial communities of excess sludge treatment process in vermifilter. Bioresource Technology, vol. 117, pp. 214-221. http://dx.doi.org/10.1016/j. biortech.2012.04.096. PMid:22613898.

LIU, Y., DU, Q., WANG, Q., YU, H., LIU, J., TIAN, Y., CHANG, C. and LEI, J., 2017. Causal inference between bioavailability of heavy metals and environmental factors in a large-scale region. Environmental Pollution, vol. 226, pp. 370-378. http://dx.doi. org/10.1016/j.envpol.2017.03.019. PMid:28457732.

MOUNTOURIS, A., VOUTSAS, E. and TASSIOS, D., 2002. Bioconcentration of heavy metals in aquatic environments: the importance of bioavailability. Marine Pollution Bulletin, 
vol. 44, no. 10, pp. 1136-1141. http://dx.doi.org/10.1016/S0025326X(02)00168-6. PMid:12474975.

MUHAMMAD, S., TAHIR SHAH, M. and KHAN, S., 2010. Arsenic health risk assessment in drinking water and source apportionment using multivariate statistical techniques in Kohistan region, northern Pakistan. Food and Chemical Toxicology, vol. 48, no. 10, pp. 2855-2864. http://dx.doi.org/10.1016/j.fct.2010.07.018. PMid:20643180.

NANNONI, F., ROSSI, S. and PROTANO, G., 2014. Soil properties and metal accumulation by earthworms in the Siena urban area (Italy). Applied Soil Ecology, vol. 77, pp. 9-17. http://dx.doi. org/10.1016/j.apsoil.2014.01.004.

NIROLA, R., MEGHARAJ, M., SAINT, C., ARYAL, R., THAVAMANI, P., VENKATESWARLU, K., NAIDU, R. and BEECHAM, S., 2016. Metal bioavailability to Eisenia fetida through copper mine dwelling animal and plant litter, a new challenge on contaminated environment remediation. International Biodeterioration $\mathcal{E}$ Biodegradation, vol. 113, pp. 208-216. http://dx.doi.org/10.1016/j. ibiod.2016.03.007.

OJEDOKUN, A.T. and BELLO, O.S., 2016. Sequestering heavy metals from wastewater using cow dung. Water Resources and Industry, vol. 13, pp. 7-13. http://dx.doi.org/10.1016/j.wri.2016.02.002.

PATTNAIK, S. and REDDY, M.V., 2011. Heavy metals remediation from urban wastes using three species of earthworm (Eudrilus eugeniae, Eisenia fetida and Perionyx excavatus). Journal of Environmental Chemistry and Ecotoxicology, vol. 3, no. 14, pp. 345-356. http://dx.doi.org/10.5897/JECE11.036.

QUENEA, K., LAMY, I., WINTERTON, P., BERMOND, A. and DUMAT, C., 2009. Interactions between metals and soil organic matter in various particle size fractions of soil contaminated with waste water. Geoderma, vol. 149, no. 3-4, pp. 217-223. http:// dx.doi.org/10.1016/j.geoderma.2008.11.037.

SELVI, A., RAJASEKAR, A., THEERTHAGIRI, J., ANANTHASELVAM, A., SATHISHKUMAR, K., MADHAVAN, J. and RAHMAN, P.K., 2019. Integrated remediation processes toward heavy metal removal/ recovery from various environments-a review. Frontiers in Environmental Science, vol. 7, pp. 66. http://dx.doi.org/10.3389/ fenvs.2019.00066.

SHARMA, D., VARMA, V.S., YADAV, K.D. and KALAMDHAD, A.S. 2017a. Evolution of chemical and biological characterization during agitated pile composting of flower waste. International Journal of Recycling of Organic Waste in Agriculture, vol. 6, no. 1, pp. 89-98. http://dx.doi.org/10.1007/s40093-017-0155-9.

SHARMA, D.K., TOMAR, S. and CHAKRABORTY, D., 2017b. Role of earthworm in improving soil structure and functioning. Current Science, vol. 113, no. 06, pp. 1064-1071. http://dx.doi. org/10.18520/cs/v113/i06/1064-1071.

SIAL, N., ABID, S., SHAHZAD, M.I., HASHIM, S., KIRMANI, F., SHAFIQUE, S., MUSAWER, A. and SAIF, I., 2017. Diversity of earthworms in district Bahawalpur, Punjab, Pakistan. Wulfenia Journal, vol. 24, no. 4, pp. 170-174.

SINGH, J. and KALAMDHAD, A.S., 2013. Reduction of bioavailability and leachability of heavy metals during vermicomposting of water hyacinth. Environmental Science and Pollution Research International, vol. 20, no. 12, pp. 8974-8985. http://dx.doi. org/10.1007/s11356-013-1848-x. PMid:23757026.
SINGH, W.R. and KALAMDHAD, A.S., 2016. Transformation of nutrients and heavy metals during vermicomposting of the invasive green weed Salvinia natans using Eisenia fetida. International Journal of Recycling of Organic Waste in Agriculture, vol. 5, no. 3, pp. 205-220. http://dx.doi.org/10.1007/s40093016-0129-3.

SUTHAR, S. and SINGH, S., 2009. Bioconcentrations of metals $(\mathrm{Fe}, \mathrm{Cu}, \mathrm{Zn}, \mathrm{Pb})$ in earthworms (Eisenia fetida), inoculated in municipal sewage sludge: do earthworms pose a possible risk of terrestrial food chain contamination? Environmental Toxicology: An International Journal, vol. 24, no. 1, pp. 25-32. http://dx.doi.org/10.1002/tox.20388. PMid:18461553.

SUTHAR, S., PANDEY, B., GUSAIN, R., GAUR, R.Z. and KUMAR, K., 2017. Nutrient changes and biodynamics of Eisenia fetida during vermicomposting of water lettuce (Pistia sp.) biomass: a noxious weed of aquatic system. Environmental Science and Pollution Research International, vol. 24, no. 1, pp. 199-207. http://dx.doi. org/10.1007/s11356-016-7770-2. PMid:27709429.

TCHOUNWOU, P.B., YEDJOU, C.G., PATLOLLA, A.K. and SUTTON, D.J., 2012. Heavy metal toxicity and the environment. In A. LUCH, ed. Molecular, clinical and environmental toxicology. Basel: Springer, pp. 133-164. http://dx.doi.org/10.1007/978-3-7643-8340-4_6.

VIJVER, M.G., VINK, J.P., MIERMANS, C.J. and VAN GESTEL, C.A., 2003. Oral sealing using glue: a new method to distinguish between intestinal and dermal uptake of metals in earthworms. Soil Biology \& Biochemistry, vol. 35, no. 1, pp. 125-132. http:// dx.doi.org/10.1016/S0038-0717(02)00245-6.

VIJVER, M.G., WOLTERBEEK, H.T., VINK, J.P. and VAN GESTEL, C.A., 2005. Surface adsorption of metals onto the earthworm Lumbricus rubellus and the isopod Porcellio scaber is negligible compared to absorption in the body. The Science of the Total Environment, vol. 340, no. 1-3, pp. 271-280. http://dx.doi. org/10.1016/j.scitotenv.2004.12.018. PMid:15752507.

WANG, K., QIAO, Y., ZHANG, H., YUE, S., LI, H., JI, X. and LIU, L., 2018. Bioaccumulation of heavy metals in earthworms from field contaminated soil in a subtropical area of China. Ecotoxicology and Environmental Safety, vol. 148, pp. 876-883. http://dx.doi. org/10.1016/j.ecoenv.2017.11.058.

WU, Y., CHEN, C., WANG, G., XIONG, B., ZHOU, W., XUE, F., QI, W., QIU, C. and LIU, Z., 2020. Mechanism underlying earthworm on the remediation of cadmium-contaminated soil. The Science of the Total Environment, vol. 728, 138904. http://dx.doi.org/10.1016/j. scitotenv.2020.138904. PMid:32570329.

YOON, G., PARK, S.M., YANG, H., TSANG, D.C., ALESSI, D.S. and BAEK, K., 2018. Selection criteria for oxidation method in total organic carbon measurement. Chemosphere, vol. 199, pp. 453-458. http:// dx.doi.org/10.1016/j.chemosphere.2018.02.074. PMid:29453072.

ŽALTAUSKAITĖ, J. and SODIENĖ, I., 2010. Effects of total cadmium and lead concentrations in soil on the growth, reproduction and survival of earthworm Eisenia fetida. Ekologija, vol. 56, no. 1-2, pp. 10-16. http://dx.doi.org/10.2478/v10055-010-0002-z.

ZHANG, H. and REYNOLDS, M., 2019. Cadmium exposure in living organisms: a short review. The Science of the Total Environment, vol. 678, pp. 761-767. http://dx.doi.org/10.1016/j. scitotenv.2019.04.395. PMid:31085492. 